\title{
Assessment of Combining Ability and Gene Action for Seed Yield and it's Contributing Traits in Cowpea (Vigna unguiculata L. Walp)
}

\author{
Anjali R. Talape ${ }^{1 *}$, P.B. Wadikar ${ }^{2}$, S.L. Waghmode ${ }^{1}$ and P.L. Tavadare ${ }^{1}$ \\ ${ }^{1}$ Department of Genetics and Plant Breeding, College of Agriculture, Latur 413512 , \\ Vasantrao Naik Marathwada Krishi Vidyapeeth, Parbhani, India \\ ${ }^{2}$ College of Agriculture, Latur 413 512, Vasantrao Naik Marathwada Krishi Vidyapeeth, \\ Parbhani, India \\ *Corresponding author
}

\section{A B S T R A C T}

\begin{abstract}
The present investigation was made to study the combining ability and gene action in cowpea. Six lines and three testers were included as parental material. Eighteen hybrids were developed and evaluated in RBD at College of Agriculture, Latur during Kharif season 2019 for 10 characters viz., days to 50 percent flowering, days to maturity, plant height at maturity, Number of branches per plant, Number of pods per plant, Number of seeds per pod, Pod length, 100 seed weight, Harvesting Index, Seed yield per plant. In the investigation line, Kashi Gauri good general combiner for Days to 50\% flowering, Days to maturity, Number of branches per plant, Number of seeds per pod, 100 seed weight, Harvesting Index, Seed yield per plant and line UV-5 was found good general combiner for plant height at maturity, Number of branches per plant, Number of pods per plant, Number of seeds per pod, Pod lenght 100 seed weight,. Seed yield per plant. Among the testers Konkan Safed was found good general combiner for Number of seeds per pod, Pod length, 100 seed weight, Harvesting Index, Seed yield per plant. Out of 18 hybrids the, the cross,UV-5 x Konkan Safed was found as best specific combiner for majority of the characters viz. seed yield per plant, number of pods per plant, 100 seed weight in desire direction. The high exhibiting SCA effect for seed yield cross Kashi Nidhi x Konkan Safed also exhibited average SCA effect for number of branches per plant, pod length, number of seeds per pod and 100 seed weight in desire direction. The variance component due to specific combining ability was greater in magnitude than that of general combining ability for all the characters except 100 seed weight, Harvesting Index, seed yield per plant, which indicated that non-additive gene action played important role for the inheritance of these traits and 100 seed weight, Harvesting index, seed yield per plant were governed by additive gene action.
\end{abstract}

\section{Introduction}

Cowpea (Vigna unguiculata (L) walp.) is an annual crop belongs to the family fabaceae with chromosome number $2 n=22$. It is selfpollinating crop having cleistogamous flowers, due to which variability in cowpea created through hybridization between 
desirable parents. The cowpea is multifunctional crop and it possesses high nutritive value. The plants are well adapted to grow under high temperature and drought and tolerate low soil fertility due to their high rated nitrogen fixation and ability to form effective symbiotic mycorrhizae, Therefore, cowpea play important role in agriculture development Nutritionally it has great potential, cowpea is a complete food minus fat its contain macronutrients and micronutrients. Among the all pulses, cowpea (Vigna unguiculata (L) walp.) is an important pulse crop it said "poor mans meat" locally known as chowli, southern pea , black eyed pea and labia from vedic time. Line $\mathrm{x}$ tester analysis been widely used for genetic analysis in large number of crop plants. It is very efficient technique for evaluating large number of inbreds for their combining ability, besides this technique also provides information on GCA and SCA, which are useful to study gene action controlling various characters to adopt appropriate breeding strategy. The concept of combining ability is meant for reducing the number of crosses to be advanced. It enables to select desirable parents and specific cross combinations. Relative amount of gca and sca effects is a foundation for any fruitful breeding program. Allard pointed out that selection of parents on the basis of performances is not a viable indication of their superior combining ability. The choice of parents should be based on complete genetic information and knowledge of combining ability of parents and not merely on yield performance.

\section{Materials and Methods}

The experimental material for the study includes six lines and three testers as male parents those were crossed and produced 18 new hybrids in Rabi 2018 and Kharif 2019. Parents, hybrids and checks were evaluated in Rabi 2018-Kharif 2019. The experimental material consists of six female lines and three tester were crossed in Line X Testers method to produce 18 hybrids. The resulting 18 hybrids, 9 parents and 1 checks were studied in randomized block design with two replications during Kharif-2019 at College of agriculture, Latur. The morphological observations on 10 characters were recorded by selecting randomly 5 competitive plants in each plot and in each replication. The mean values of all treatments for the characters under study were worked out. Standard error and critical difference at 1 and $5 \%$ level of significance were calculated by using the formula (Panse and Sukhatme, 1967). Combining ability analysis and the testing of significance of different genotypes was based on the procedure given by kempthorne (1957). In order to understand the nature of gene action, the ratio was worked out by taking in to account the estimated variance of gca and sca. It is generally accepted in biometrics that for each of characters studied, where the variance ratio is greater than one, the gene action is additive and wherever the ratio is less than one; the gene action is nonadditive.

\section{Results and Discussion}

The mean sum of squares for parents and crosses showed significant differences for all the characters, indicating presence of the sufficient variability in the genetic material. The analysis of variance for combining ability (Table 1 and 2) revealed significant differences among treatment, parents and crosses for all the characters (except days to $50 \%$ flowering, no. of seeds per pod for Parent $v / s$ crosses). The mean sum of squares for parents further partitioning of the variance due to various source of variation also showed the significant differences for all the characters under study. The magnitude of specific combining ability variances was larger than general combining ability 
variances for the characters days to 50 percent flowering, days to maturity, plant height at maturity, Number of branches per plant, Number of pods per plant, Number of seeds per pod, Pod length, 100 seed weight. The magnitude of general combining ability variances was larger than specific combining ability for harvesting index and seed yield per plant.

Perusal of gca effects of 9 parents for 10 characters reveals that the line, Kashi Gauri good general combiner for Days to $50 \%$ flowering, Days to maturity, Number of branches per plant, Number of seeds per pod, 100 seed weight, Harvesting Index, Seed yield per plant and line UV-5 was found good general combiner for plant height at maturity, Number of branches per plant, Number of pods per plant, Number of seeds per pod, Pod lenght 100 seed weight,. Seed yield per plant. Also line Kashi Kanchan was found good general combiner for Days to 50\% flowering and Days to maturity. Line GDVC-2 was found good general combiner for Days to $50 \%$ flowering and Pod length. Similarly among the testers Konkan Safed was found good general combiner for Number of seeds per pod, Pod length, 100 seed weight, Harvesting Index, Seed yield per plant. Also tester Pusa Komal was found good general combiner for plant height at maturity, Number of branches per plant, Pod length and seed yield per plant. Tester GC-3 was found good general combiner for Days to $50 \%$ flowering and Days to maturity. The present results thus suggest that these parents possessed high concentration of favorable genes for the respective traits and may be utilized in crossing programme to develop the varieties/hybrids containing majority of desirable characteristics in cowpea (Table 3 and 4).

The estimate of SCA effects revealed that none of the crosses was superior simultaneously for all the characters. Similar results were also reported by Ayo-Vaughan et al., (2011). However, the best hybrids on the basis of significant and positive SCA effect for seed yield per plant were UV-5 x Konkan Safed and UV-5 x Pusa Komal. Among the crosses, the cross,UV-5 x Konkan Safed was found as best specific combiner for majority of the characters viz. seed yield per plant, number of pods per plant, 100 seed weight in desire direction. The high exhibiting SCA effect for seed yield cross Kashi Nidhi x Konkan Safed also exhibited average SCA effect for number of branches per plant, pod length, number of seeds per pod and 100 seed weight in desire direction (Table 5).

The high SCA effect for poor x good (Kashi Nidhi x Konkan Safed) parents might be due to Thus, crosses involving one good general combiner indicate an additive $\mathrm{x}$ dominance type of gene interaction could be utilized to produce desirable transgressive seggregants in subsequent generation (Patel et al., 2010) and for good $\mathrm{x}$ good combination had both dominant type gene action Uma (2010) and Patil and Navale (2006). While in the cross of good x good (UV-5 x Pusa Komal) parents, magnitude of SCA was higher due to good combiner or complementary epistatic effect in the same direction. Thus, crosses showing high sca effect involving either one or both are the good parent for good general combiner parent could be successfully exploited for varietal improvement (Table 6).

The gca effects of the line and tester and sca effect of crosses (Kashi Gauri x Konkan Safed) indicated that the cross between one or both good general combiners were not the best specific combinations for seed yield. Even with the same amount of heterotic effects, the SCA effect may be lower where mean performance of their parents is higher. This suggesting that, the estimate of SCA effect may not always lead to a correct choice of hybrid combination, Grafius (1964) reported that the yield is the end product of 
multivariable interaction between yield components. Thus, the choice of best cross combination on the basis of per se performance could be more realistic and suitable for exploitation of heterosis for yield improvement in cowpea. These results are in agreement with Patil and Navale (2006), Patel et al., (2010) and Kumar et al., (2017).

For days to $50 \%$ flowering negative sca effects are considered to be desirable. Among crosses, the only one cross, Kashi Gauri $\mathrm{x}$ Konkan Safed exhibited highest (-6.222) significant and negative SCA effect. However, the cross Kashi Gauri x GC-3 (4.278) showed positive SCA effect and proved poor general combiner for earliness.

The negative SCA effects are considered to be desirable for days to maturity. Estimates of specific combining ability effects of $F_{1} s$ diverged from -6.528 (Kashi Kanchan x Pusa Komal) to 6.306 (Kashi Gauri x Pusa Komal). The cross, Kashi Kanchan x Pusa Komal (6.528) followed by Kashi Gauri x Konkan Safed(-5.611) and GDVC-2 x Pusa Komal (4.861) exhibited significant and negative SCA effect in desired direction. Whereas, the cross Kashi Gauri x Pusa Komal (6.306) was found with significant positive SCA effect in undesired direction.

Among 18 crosses, five crosses recorded positively SCA effect for plant height at maturity. Cross, GDVC-2 x Konkan Safed (18.11) followed by GC-6 x Konkan Safed (16.193) and Kashi Gauri x GC-3 (15.676) exhibited highly significant and positive SCA effect in positive direction whereas, the cross GC-6 x GC-3 (-17.53) depicted significant negative SCA effect in negative direction.

Estimates of SCA effects for number of branches per plant. Among the 18 crosses, seven showed positive SCA effect. Cross, GC-6 x Pusa Komal (2.040) recorded highest significant and positive SCA effect while, Kashi Nidhi (-2.493) recorded negative SCA effect for this trait.

Under the investigation for this character number of pods per plant, the sca value for crosses were fluctuated between -4.863 (GC-6 $\mathrm{x}$ GC-3) to 2.946 (Kashi Kanchan x GC-3). Among the 18 crosses, none crosses showed significantly positive SCA effect.

Among the 18 crosses, four crosses showed positively significant SCA effects for the character pod length. Whereas, Kashi Kanchan (3.810) exhibited highest positively value for SCA effects followed by UV-5 x Pusa Komal (2.122), Kashi Nidhi x Konkan Safed (2.001) and GC-6 x Konkan Safed (1.718) .

For the number of seeds per pod, five crosses exhibited positive SCA effect in desired direction. The cross, GC-6 x Konkan Safed registered highest significant and positive SCA effect (1.946) followed by Kashi Kanchan x GC-3 (1.079) and Kashi Nidhi x Konkan Safed (1.071). However, the cross Kashi Kanchan x Konkan Safed (-1.913) depicted negative significant SCA effect.

In the 100 seed weight estimates of specific combing ability effects -11.11 (Kashi Gauri x GC-3) to 11.163 (Kashi Gauri x Pusa Komal) and Kashi Gauri x Pusa Komal (11.163) had exhibited highest positively significant SCA effects followed by GDVC-2 x GC-3 (5.917) and GDVC-2 x GC-6 x GC-3 (4.233).

For the character harvest index highest positive significant specific combining ability effects followed by GDVC-2 x Pusa Komal (1.329) and UV-5 x Konkan Safed (1.175), respectively. Estimates of specific combining ability effects for $F_{1} s$ varied from -4.667 (Kashi Kanchan x Pusa Komal) to 9.200 (Kashi Kanchan x GC-3). Among the 18 cross 
combination, four crosses viz., Kashi Kanchan x GC-3 (9.200), Kashi Nidhi x Konkan Safed (7.500), GDVC-2 x GC-3 (4.333) and UV-5 x Pusa Komal (3.433) exhibited significant and positive SCA effect, however four crosses across 18 exhibited non-significant but positive SCA effect for this character.

Table.1 Analysis of variance for different character in cowpea

\begin{tabular}{|c|c|c|c|c|}
\hline $\begin{array}{c}\text { Sr. } \\
\text { No. }\end{array}$ & Characters & $\begin{array}{c}\text { Replication } \\
\mathbf{1}(\mathbf{d . f .})\end{array}$ & $\begin{array}{c}\text { Treatment } \\
\mathbf{2 7}(\mathbf{d . f .})\end{array}$ & $\begin{array}{c}\text { Error } \\
\mathbf{2 7}(\mathbf{d . f} .)\end{array}$ \\
\hline $\mathbf{1}$ & Days to 50\% flowering & 0.46 & $34.56^{* *}$ & 2.03 \\
\hline $\mathbf{2}$ & Days to maturity & 1.50 & $50.85^{* *}$ & 4.03 \\
\hline $\mathbf{3}$ & Plant height at maturity (cm) & 19.62 & $644.58^{* *}$ & 24.65 \\
\hline $\mathbf{4}$ & Number of branches per plant & 0.102 & $4.02^{* *}$ & 0.22 \\
\hline $\mathbf{5}$ & Number of pods per plant & 0.303 & $58.96^{* *}$ & 5.13 \\
\hline $\mathbf{6}$ & Pod length (cm) & 0.082 & $8.98^{* *}$ & 0.27 \\
\hline $\mathbf{7}$ & Number of seeds per pod (g) & 1.02 & $4.45^{* *}$ & 0.27 \\
\hline $\mathbf{8}$ & $\mathbf{1 0 0}$ seed weight (g) & 0.644 & $222.22^{* *}$ & 3.18 \\
\hline $\mathbf{9}$ & Harvesting index (\%) & 0.024 & $7.49^{* *}$ & 0.25 \\
\hline $\mathbf{1 0}$ & Seed yield per plant (g) & 0.64 & $211.41^{* *}$ & 4.82 \\
\hline ** and $*$ indicates significant at 1\% and 5\% respectively. & & \\
\hline
\end{tabular}

Table.2 Analysis of variance for combining ability

\begin{tabular}{|c|c|c|c|c|c|c|c|c|}
\hline Characters & $\begin{array}{c}\text { Parents } \\
\text { MSS }\end{array}$ & $\begin{array}{l}\text { Lines } \\
\text { MSS }\end{array}$ & $\begin{array}{l}\text { Tester } \\
\text { MSS }\end{array}$ & $\begin{array}{c}\text { Crosses } \\
\text { MSS }\end{array}$ & $\begin{array}{c}\text { Parents v/s } \\
\text { Crosses } \\
\text { MSS }\end{array}$ & $\begin{array}{l}\delta^{2} \text { gca } \\
\text { (ave.) }\end{array}$ & $\delta^{2}$ sca & $\begin{array}{c}\text { Error } \\
\text { MSS }\end{array}$ \\
\hline d.f. & 8 & 5 & 2 & 17 & 1 & & & 27 \\
\hline DF & $28.097 * *$ & $23.933 * *$ & $43.166^{* *}$ & $39.267 * *$ & 6.259 & $5.2111^{*}$ & $13.4523 * *$ & 2.039 \\
\hline DM & $26.888 * *$ & $29.883 * *$ & $32.166 * *$ & $63.478 * *$ & $28.009^{*}$ & 7.9167* & $21.9613 * *$ & 4.038 \\
\hline PH (cm) & $469.173 * *$ & $624.657 * *$ & $311.540 * *$ & $532.665^{* *}$ & $3950.045^{* *}$ & $37.6792 *$ & $178.3903 * *$ & 24.659 \\
\hline NB & $3.428 * *$ & $1.896 * *$ & $8.211 * *$ & $3.651 * *$ & $15.075^{* *}$ & -0.3509 & $2.4529 * *$ & 0.220 \\
\hline NP & $66.167 *$ & $20.955^{* *}$ & $114.746 * *$ & $49.724 * *$ & $158.292 * *$ & $6.0640 * *$ & $8.5507 * *$ & 5.135 \\
\hline PL(CM) & $7.103^{* *}$ & 3.720 ** & $3.151^{* *}$ & 9.076 ** & $22.458 * *$ & 0.5696 & $4.3898 * *$ & 0.272 \\
\hline NS & $5.670 * *$ & $2.697 * *$ & $4.095^{* *}$ & $4.141^{* *}$ & 0.03169 & $0.3014^{*}$ & $1.4055^{* * *}$ & 3.082 \\
\hline SW & $37.833 * *$ & $50.977 * *$ & $13.041 * *$ & $244.873 * *$ & $1312.172 * *$ & $45.0604 * *$ & $41.5548^{* *}$ & 3.179 \\
\hline HI (\%) & $3.848^{* *}$ & $3.846^{* *}$ & $0.605^{* *}$ & $9.398 * *$ & $4.102^{* *}$ & $2.0346 * *$ & $1.7408 * *$ & 0.254 \\
\hline SYP(g) & $56.055^{* *}$ & $38.332 * *$ & 41.071. & $192.235^{* *}$ & $1780.228^{* *}$ & $48.5040 * *$ & $24.6368^{* *}$ & 4.820 \\
\hline
\end{tabular}

** and * indicates significant at $1 \%$ and $5 \%$ respectively.

Whereas,

$\mathrm{DF}=$ Days to $50 \%$ flowering, NS =No. of seeds per pod, $\mathrm{DM}=$ Days to maturity, $\mathrm{PL}=\mathrm{Pod}$ length, NB $=$ No. of Branches per plant $(\%), \mathrm{PH}=$ Plant height at maturity $(\mathrm{cm}), \mathrm{HI}=$ Harvesting index, $\mathrm{SW}=100$-seed weight, $\mathrm{NP}=$ No. of pods per plant, $\mathrm{SYP}=$ Seed yield per plant $(\mathrm{g})$ 
Table.3 Estimates of general combining ability (GCA) effect of lines for ten characters in cowpea

\begin{tabular}{|c|c|c|c|c|c|c|}
\hline Characters & $\begin{array}{c}\text { Kashi } \\
\text { Kanchan }\end{array}$ & $\begin{array}{l}\text { Kashi } \\
\text { Gauri }\end{array}$ & GC-6 & GDVC-2 & $\begin{array}{l}\text { Kashi } \\
\text { Nidhi }\end{array}$ & UV-5 \\
\hline Days to $50 \%$ flowering & $-1.444 *$ & $-1.611^{*}$ & $1.889 * *$ & $-2.444 * *$ & $1.722 * *$ & $1.889 * *$ \\
\hline Days to maturity & $-2.805^{* *}$ & $-2.639 * *$ & $3.028 * *$ & -1.472 & 1.528 & $2.361 *$ \\
\hline $\begin{array}{l}\text { Plant height at } \\
\text { maturity (cm) }\end{array}$ & 1.807 & 2.607 & $8.515 * *$ & $-20.51 * *$ & -4.060 & $11.640 * *$ \\
\hline $\begin{array}{l}\text { Number of branches } \\
\text { per plant }(\mathrm{cm})\end{array}$ & -0.282 & $0.443^{*}$ & -0.215 & 0.151 & $-0.532 *$ & $0.435^{*}$ \\
\hline $\begin{array}{l}\text { Number of pods per } \\
\text { plant (g) }\end{array}$ & 0.062 & $-3.113 * *$ & 0.846 & $-3.104 * *$ & $-2.521 *$ & $7.829 * *$ \\
\hline Pod length $(\mathrm{cm})$ & $-0.701 * *$ & 0.432 & $-0.451 *$ & $0.582 *$ & $-0.535^{*}$ & $0.674^{*}$ \\
\hline $\begin{array}{l}\text { Number of seeds per } \\
\text { pod }\end{array}$ & -0.396 & $0.454 *$ & $-0.804 * *$ & $-0.979 * *$ & 0.121 & $1.604 * *$ \\
\hline 100 seed weight $(\mathrm{g})$ & $-9.676 * *$ & $7.046 * *$ & $-5.904 * *$ & $-3.588 * *$ & -1.204 & $13.329 * *$ \\
\hline Harvesting index (\%) & -0.046 & $2.304 * *$ & $-0.662 * *$ & $-1.663 * *$ & $0.738 * *$ & $-0.738 * *$ \\
\hline Seed yield per plant(g) & $-7.125 * *$ & $6.558 * *$ & -1.675 & $-4.675 * *$ & $-2.458 *$ & $9.375 * *$ \\
\hline
\end{tabular}

$* *$ and $*$ indicates significant at $1 \%$ and $5 \%$, respectively.

Whereas, $\mathrm{DF}=$ Days to $50 \%$ flowering, NS $=$ No. of seeds per pod, DM $=$ Days to maturity, PL $=$ Pod length, NB $=$ No. of Branches per plant $(\%), \mathrm{PH}=$ Plant height at maturity $(\mathrm{cm}), \mathrm{HI}=$ Harvesting index, $\mathrm{SW}=100$-seed weight, $\mathrm{NP}=$ No. of pods per plant, $\mathrm{SYP}=$ Seed yield per plant $(\mathrm{g})$

Table.4 Estimates of general combining ability (GCA) effect of testers for nine characters in cowpea

\begin{tabular}{|l|c|c|c|}
\hline \multicolumn{1}{|c|}{ Characters } & GC-3 & Pusa Komal & $\begin{array}{c}\text { Konkan } \\
\text { Safed }\end{array}$ \\
\hline Days to 50\% flowering & $-3.278^{* *}$ & $0.056^{* *}$ & $3.222^{* *}$ \\
\hline Days to maturity & $-4.472^{* *}$ & 1.028 & $3.444^{* *}$ \\
\hline $\begin{array}{l}\text { Plant height at } \\
\text { maturity (cm) }\end{array}$ & $-6.543^{* *}$ & 8.011 & -1.468 \\
\hline $\begin{array}{l}\text { Number of branches } \\
\text { per plant (cm) }\end{array}$ & $-0.386^{*}$ & $-0.560^{* *}$ & -0.174 \\
\hline $\begin{array}{l}\text { Number of pods per } \\
\text { plant (g) }\end{array}$ & 1.071 & $-2.317 * *$ & 1.246 \\
\hline Pod length(cm) & $-1.610^{* *}$ & $1.278^{* *}$ & $0.322^{*}$ \\
\hline $\begin{array}{l}\text { Number of seeds per } \\
\text { pod }\end{array}$ & $-0.813^{* *}$ & 0.283 & $0.529 * *$ \\
\hline $\mathbf{1 0 0}$ seed weight(g) & $-5.517 *$ & $-1.946^{* *}$ & $7.463^{* *}$ \\
\hline Harvesting index $(\%)$ & $-1.729 * *$ & 0.171 & $1.558^{* *}$ \\
\hline Seed yield per plant(g) & $-8.533^{* *}$ & $1.833^{* *}$ & $6.700^{* *}$ \\
\hline
\end{tabular}

** and * indicates significant at $1 \%$ and $5 \%$, respectively 
Table.5 Estimates of specific combining ability (SCA) effects

\begin{tabular}{|c|c|c|c|c|c|c|}
\hline $\begin{array}{l}\text { Sr. } \\
\text { No. }\end{array}$ & Characters & $\begin{array}{c}\text { Days to } 50 \% \\
\text { flowering }\end{array}$ & $\begin{array}{l}\text { Days to } \\
\text { maturity }\end{array}$ & $\begin{array}{l}\text { Plant height } \\
\text { at maturity } \\
(\mathrm{cm})\end{array}$ & $\begin{array}{l}\text { Number of } \\
\text { branches per } \\
\text { plant }(\mathbf{c m})\end{array}$ & $\begin{array}{c}\text { Number of } \\
\text { pods per } \\
\text { plant }(g)\end{array}$ \\
\hline & Crosses & 1 & 2 & 3 & 4 & 5 \\
\hline 1 & KASHI KANCHAN x GC-3 & $3.111 * *$ & $5.972 * *$ & 4.026 & $-0.9728 * *$ & 2.946 \\
\hline 2 & KASHI KANCHAN x PUSA KOMAL & $-2.722 *$ & $-6.528 * *$ & 1.122 & $-0.368 *$ & -2.267 \\
\hline 3 & KASHI KANCHAN x KONKAN SAFED & -0.389 & 0.556 & -5.149 & $1.340 * *$ & -0.679 \\
\hline 4 & KASHI GAURI X GC-3 & $4.278 * *$ & $-0.694 * *$ & $15.676^{* *}$ & $0.778^{*}$ & 1.621 \\
\hline 5 & KASHI GAURI x PUSA KOMAL & -1.944 & $6.306^{* *}$ & $-8.278 *$ & 0.007 & -2.167 \\
\hline 6 & KASHI GAURI x KONKAN SAFED & $-6.222 * *$ & $-5.611 * *$ & $-7.399 * *$ & $-0.785^{*}$ & 0.546 \\
\hline 7 & GC-6 x GC-3 & $-3.222 * *$ & -1.361 & $-17.53 * *$ & $0.036 * *$ & $-4.863 * *$ \\
\hline 8 & GC-6 x PUSA KOMAL & $3.444 * *$ & 0.139 & 1.339 & $2.040 * *$ & -2.450 \\
\hline 9 & GC-6 x KONKAN SAFED & -0.222 & 1.222 & $16.193 * *$ & $-2.076^{* *}$ & -2.412 \\
\hline 10 & GDVC- 2 x GC-3 & -0.389 & $3.139 *$ & -5.957 & $-1.431 * *$ & -3.188 \\
\hline 11 & GDVC- 2 x PUSA KOMAL & $-2.722 *$ & $-4.861 * *$ & $-12.16 * *$ & 0.524 & 2.500 \\
\hline 12 & GDVC- $2 \times$ KONKAN SAFED & 3.111 & 1.722 & $18.11 * *$ & $0.907 *$ & 0.688 \\
\hline 13 & KASHI NIDHI x GC-3 & -3.056 & -2.361 & 1.743 & $1.253 * *$ & $-4.371 *$ \\
\hline 14 & KASHI NIDHI X PUSA KOMAL & -0.889 & 0.639 & $7.889 *$ & $-2.493 * *$ & 2.217 \\
\hline 15 & KASHI NIDHI x KONKAN SAFED & 3.944 & 1.722 & $-9.632 *$ & $1.240 * *$ & 2.154 \\
\hline 16 & UV-5 x GC-3 & -0.722 & $-4.694 * *$ & 2.043 & 0.336 & -1.871 \\
\hline 17 & UV-5 x PUSA KOMAL & 1.009 & 4.306 & $10.08 *$ & 0.290 & 2.167 \\
\hline 18 & UV-5 x KONKAN SAFED & -0.222 & 0.389 & $-12.13 * *$ & -0.626 & -0.296 \\
\hline
\end{tabular}

$* *$ and $*$ indicates significant at $1 \%$ and $5 \%$, respectively 
Estimates of specific combining ability (SCA) effects

\begin{tabular}{|c|c|c|c|c|c|c|}
\hline $\begin{array}{l}\text { Sr. } \\
\text { No. }\end{array}$ & Characters & $\begin{array}{c}\text { Pod } \\
\text { length }(\mathrm{cm})\end{array}$ & $\begin{array}{c}\text { Number of } \\
\text { seeds per pod }\end{array}$ & $\begin{array}{c}100 \text { seed } \\
\text { weight }(g)\end{array}$ & $\begin{array}{l}\text { Harvesting } \\
\text { index }(\%)\end{array}$ & $\begin{array}{c}\text { Seed yield } \\
\text { per plant } \\
\text { (g) }\end{array}$ \\
\hline & Crosses & 6 & 7 & 8 & 9 & 10 \\
\hline 1 & KASHI KANCHAN x GC-3 & $3.810^{* *}$ & $1.079 * *$ & -0.667 & $-2.038 * *$ & $9.200 * *$ \\
\hline 2 & KASHI KANCHAN x PUSA KOMAL & $-1.578 * *$ & $0.833^{*}$ & $-3.213 *$ & $0.812^{*}$ & $-4.667 * *$ \\
\hline 3 & KASHI KANCHAN x KONKAN SAFED & $-2.232 * *$ & $-1.913 * *$ & $3.879 * *$ & $1.225 * *$ & $-4.533 * *$ \\
\hline 4 & KASHI GAURI X GC-3 & -0.624 & 0.079 & $-11.11 * *$ & $1.963 * *$ & 0.567 \\
\hline 5 & KASHI GAURI x PUSA KOMAL & 0.389 & -0.167 & $11.163 * *$ & -0.738 & 0.650 \\
\hline 6 & KASHI GAURI x KONKAN SAFED & 0.235 & 0.088 & -0.046 & $-1.225 * *$ & -1.217 \\
\hline 7 & GC-6 x GC-3 & $-2.090 * *$ & $-1.213 * *$ & $4.233 * *$ & -0.071 & -0.900 \\
\hline 8 & GC-6 x PUSA KOMAL & 0.372 & -0.733 & -0.338 & 0.129 & 0.883 \\
\hline 9 & GC-6 x KONKAN SAFED & $1.718 * *$ & $1.946 * *$ & $-3.896 * *$ & -0.058 & 0.017 \\
\hline 10 & GDVC- 2 x GC-3 & -0.474 & 0.662 & $5.917 * *$ & -0.071 & -2.300 \\
\hline 11 & GDVC- 2 x PUSA KOMAL & 0.389 & -0.283 & $-5.904 * *$ & $1.329 * *$ & $4.333^{*}$ \\
\hline 12 & GDVC- $2 \times$ KONKAN SAFED & 0.085 & -0.379 & -0.012 & $-1.258 * *$ & -2.033 \\
\hline 13 & KASHI NIDHI x GC-3 & -0.307 & -0.438 & -0.517 & 0.129 & -2.867 \\
\hline 14 & KASHI NIDHI X PUSA KOMAL & $-1.694 * *$ & -0.633 & $-3.588 *$ & -0.271 & $-4.633 * *$ \\
\hline 15 & KASHI NIDHI x KONKAN SAFED & $2.001 * *$ & $1.071 * *$ & $4.104 * *$ & 0.142 & $7.500 * *$ \\
\hline 16 & UV-5 x GC-3 & -0.315 & -0.171 & 2.150 & 0.087 & $-3.700^{*}$ \\
\hline 17 & UV-5 x PUSA KOMAL & $2.122 * *$ & $0.983 *$ & 1.879 & $-1.263 * *$ & $3.433^{*}$ \\
\hline 18 & UV-5 x KONKAN SAFED & $-1.807 * *$ & -0.812 & $-4.029 * *$ & $1.175^{* *}$ & 0.267 \\
\hline
\end{tabular}

$* *$ and $*$ indicates significant at $1 \%$ and $5 \%$, respectively 
Table.6 Estimation of gene action for ten characters

\begin{tabular}{|c|c|c|c|c|c|}
\hline $\begin{array}{l}\text { Sr. } \\
\text { No. }\end{array}$ & Character & $\begin{array}{l}\text { Variance } \\
\text { gca }\end{array}$ & $\begin{array}{l}\text { Variance } \\
\text { sca }\end{array}$ & $\begin{array}{l}\text { Ratio var. } \\
\text { gca /var.sca }\end{array}$ & Gene action \\
\hline 1 & Days to $50 \%$ flowering & $5.2111 *$ & $13.4523 * *$ & 0.3873 & Non-Additive \\
\hline 2 & Days to maturity & $7.9167 *$ & $21.9613 * *$ & 0.33604 & Non-additive \\
\hline 3 & $\begin{array}{l}\text { Plant height at } \\
\text { maturity }(\mathrm{cm})\end{array}$ & $37.6792 *$ & $178.3903 * *$ & 0.2112 & Non-additive \\
\hline 4 & $\begin{array}{l}\text { Number of branches } \\
\text { per plant }\end{array}$ & -0.3509 & $2.4529 * *$ & -0.1430 & Non-additive \\
\hline 5 & $\begin{array}{l}\text { Number of pods per } \\
\text { plant }\end{array}$ & $6.0640 * *$ & $8.5507 * *$ & 0.7091 & Non-additive \\
\hline 6 & $\begin{array}{l}\text { Number of seeds per } \\
\text { pod }\end{array}$ & 0.5696 & $4.3898 * *$ & 0.1297 & Non-dditive \\
\hline 7 & Pos length (cm) & $0.3014 *$ & $1.4055^{* *}$ & 0.2234 & Non-additive \\
\hline 8 & 100 seed weight $(\mathrm{g})$ & $45.0604 * *$ & $41.5548 * *$ & 1.0843 & Additive \\
\hline 9 & Harvesting index $(\%)$ & $2.0346 * *$ & $1.7408 * *$ & 1.1687 & Additive \\
\hline 10 & Seed yield per plant(g) & $48.5040 * *$ & $24.6368 * *$ & 1.9687 & Additive \\
\hline
\end{tabular}

$* *$ and $*$ indicates significant at $1 \%$ and $5 \%$, respectively

The information on nature of gene action for yield and yield component traits in different population is imperative for planning effective breeding programme. In the present study the variance due to SCA was greater than variance due to GCA for all characters except 100 seed weight, harvesting index and seed yield per plant. Where as presence of additive type of gene action for characters viz., 100 seed weight, harvesting index and seed yield per plant was confirmed by the ratio of $\left(\delta^{2} \mathrm{gca} / \delta^{2} \mathrm{sca}\right)$ was more than unity for characters indicating additive gene action. GCA:SCA ratio showed less than unity which is expressed non-additive gene action. In Such situation development of hybrids is the better way to get good results. Similar results were reported earlier by Thiyagarajan et al.,(1993), Hazra et al., (1996), Romanus et al., (2008), Uma et al., (2010).

In conclusion, analysis of variance for combining ability revealed that, mean square due to SCA were higher in magnitude than GCA for all the characters except 100 seed weight, harvesting index, seed yield signifying preponderance of non-additive gene action among the hybrids, thus non additive gene action could be exploited by heterosis breeding.

The lines, Kashi Gauri and UV-5 were found good general combiner for seven characters including seed yield followed by tester Konkan Safed for five characters. Good general combining ability of lines Kashi Gauri or UV-5 and also tester Konkan Safed for one or more yield components might have resulted into high combining ability for cowpea seed yield. Thus, close relation between GCA and per se performance could be used as criteria to select the parents involve them in breeding programme for developing high yielding varieties.

\section{References}

Ayo-Vaughan, M.A., Omolayo Johnson Ariyo and Christopher Olusanya Alake (2011). Combining ability and genetic 
components for pod and seed traits in cowpea lines. Italian J. Agron., 8: 7378.

Grafius, J. E. 1964. Ageometry of plant breeding, Crop Science, 4: 241-246.

Hazara, P., Das, P. and Som, M. (1996). Combining ability for pod yield and seed protein in cowpea (Vigna unguiculata L. walp.) Ind. J. Genet., 56(4):553-555.

Kempthorne, O. (1957). An introduction of genetic statistics. John Willey \& Sons Inc. New York, USA: 468-473.

Kumar, S., Sridhar, K., Kumar, V. and Kulkarni, N. S. (2017). Combining ability analysis in dual purpose in cowpea (Vigna unguiculata L. walp.). Plant Archives, 17(2): 919-923.

Panse, V.G. and Sukhatme, P.Y. (1967). "Statistical methods for Agricultural workers". ICAR, New Delhi. 2 nd edition.

Patel, S. P, Bharodia, P. S. and Kakade, D. K. (2010). Concept of general and specific combining ability in relation to diallel crossing system. Int. J. Agric. Sci., 6(1): 135-137.

Patil, H. E. and Navale, P. A. (2006). Combining ability in cowpea (Vigna unguiculata L. Walp.) Legume Res., 29(4): $270-273$.

Romanus, K. G., Hussein, S. and Mashela, W. P. (2008). Combining ability analysis and association of yield and yield components among selected cowpea lines. Euphotic, 162: 205-210.

Thiyagarajan, K., Natarajan, C., Rathnaswamy, R. and Rajesekaran, S. (1993). Combining ability for yield and its components in cowpea [Vigna unguiculata (L.) Walp]. Madras Agric. J., 80(3): 124-129.

Uma, M. S. and Kalubowila, I. (2010). Line x tester analysis for yield and rust resistance in cowpea [Vigna unguiculata (L.) Walp]. Electronic Journal of Plant Breeding, 1(3): 254267.

\section{How to cite this article:}

Anjali R. Talape, P.B. Wadikar, S.L. Waghmode and Tavadare, P.L. 2020. Assessment of Combining Ability and Gene Action for Seed Yield and it's Contributing Traits in Cowpea (Vigna unguiculata L. Walp). Int.J.Curr.Microbiol.App.Sci. 9(12): 1788-1797. doi: https://doi.org/10.20546/ijcmas.2020.912.212 